\title{
The political economy of global tree plantation expansion : a review
}

\author{
Kröger, Markus
}

2014-03-20

Kröger , M 2014 , ' The political economy of global tree plantation expansion : a review ' , Journal of Peasant Studies , vol. 41 , no. 2 , pp. 235-261 . https://doi.org/10.1080/03066150.2014.890596

http://hdl.handle.net/10138/154651

https://doi.org/10.1080/03066150.2014.890596

acceptedVersion

Downloaded from Helda, University of Helsinki institutional repository.

This is an electronic reprint of the original article.

This reprint may differ from the original in pagination and typographic detail.

Please cite the original version. 


\title{
Markus Kröger (2014) The political economy of global tree plantation expansion: a review, The Journal of Peasant Studies, 41:2, 235-261, DOI:10.1080/03066150.2014.890596
}

\section{Post-print version. For original, and page numbers, please see:}

\section{http://dx.doi.org/ 10.1080/03066150.2014.890596}

Markus Kröger is an Academy of Finland post-doctoral researcher at the University of Helsinki, Department of Political and Economic Studies, with a PhD in Political Science. He has published several articles and a book on the issues of natural resource politics, land grabbing, social movement outcomes, the politics of forestry development and rural changes in Latin America. His most recent book is Contentious agency and natural resource politics. Email: markus.kroger@gmail.com

\begin{abstract}
This contribution analyses the recent global expansion of different types of tree plantations. A literature review collates accounts from recent academic publications and by NGOs, and is accompanied by field research and interview observations about the causal processes, central features and likely futures of contemporary tree plantation expansion. I will analyse the political and spatial causalities explaining varieties and commonalities in expansion style and pace, with elaboration on the applied and empirical significance of these findings for peasant studies. The literature on environmental and developmental impacts of tree plantation expansion is also surveyed.
\end{abstract}

\section{Keywords}

- industrial tree plantations,

- forest industry,

- capitalism,

- power,

- land grabbing,

- smallholders,

- space,

- $\underline{\text { flextrees }}$

\section{Introduction}

This contribution analyses the political economy of forest industry tree plantations (TPs) across the globe by a comprehensive review of the current state of knowledge on their expansion. The reviewed material includes Food and Agriculture Organization (FAO) data on TPs, existing academic literature, nongovernmental organizations' (NGOs') publications, movement material, official documents, interviews and discussions with 
specialists, foresters, company directors, officials and activists aware of the recent changes, field research observations from plantation areas, and extensive Google searches to locate articles from local and global newspapers, research institutions, and other bodies on TP expansion. I covered hundreds of reports written mostly in the past decade and will present a bibliography of key texts. The primary data I collected by in-depth ethnographic field research, participant observation in pulp investment and other TP areas in South America and Finland between 2004 and 2011, in India in 2010 and 2013 and in visits to companies' headquarters in Finland and Brazil. Two hundred semi-structured interviews with key industry, state and civil society actors were conducted. Participant observation was also undertaken in impacted areas, social movements, NGOs, companies and state institutions. The aim is to illustrate where we stand now in terms of knowledge, introduce the key explanations on causes and impacts by the application of a specific political economy framework, summarize results and outline areas needing further inquiry.

M ost of the research on current large-scale land deals has focused on food production. However, a large parcel of land-use, access and control takes place in non-edible industries, such as forestry. The share of new nonfood land access, for mining, forestry, energy and conservation purposes, among others, has been significant. For example, in Latin America, the two most important non-food sectors in terms of land use are fast-growing forestry plantations (such as eucalyptus) and conservation (Borras et al. 2012). The literature on large-scale land deals has started to deal with these. Fairhead et al. (2012) review a collection of essays on green grabs, mostly dealing with situations where conservation schemes have displaced people. Tree plantations have received less attention in this literature, despite being an essential part of the new emerging 'bio'- or 'green'economy. ${ }^{1}$ I will bridge this gap in knowledge by a comprehensive global analysis on the expansion of TPS.

The review of expanding non-food resource exploitation carries potentially significant importance in the academic and political debate on rapid agrarian change of the past years caused particularly by large-scale land deals. As non-edible crops have been left out of the analysis of land grabbing, narratives might be misrepresenting what is actually happening and why. An overt focus on food (security) as a driver misses more general phenomena explaining large-scale land deals, such as the newly emerged 'flex crop complex', the continuing importance of livestock, the sharp increase in demands for natural resources by newly emerged centres of capital, and responses to policies linked to climate change mitigation strategies (Borras et al. 2012). In particular, the notion of 'flex crops' (crops that have multiple uses - food, feed, fuel, industrial material that can be easily and flexibly interchanged), coined by Borras et al. $(\underline{2012}, 851)$, is an important analytical framework in examining crops and commodities associated with land grabbing today, including the expansion of tree plantation.

It is likely that flex trees will play an important role in future expansion of TPs as traditional industrial purposes (pulp, timber) already increasingly overlap with energy (e.g. woodchip- and pulp-based diesel) sector and conservation and climate change mitigation initiatives (e.g. REDD+, Reducing Emissions from Deforestation and Forest Degradation "plus" conservation, the sustainable management of forests and enhancement of forest carbon stocks).

To understand the quality and extent of land grabbing in its totality and sub-parts, sector-specific politics should be analysed in detail. A detailed focus on the forest industry allows (a later) comparison with other industries and enables the studying of industry-specific expansion logic and impacts. It would be hard to make 
such analysis as will be made here in one paper if including, for example, oil palm plantations, whose political economy and ecology differ greatly from forest industry plantations. ${ }^{2}$ Oil palm and rubber plantations are considered agriculture and not forestry by the International Standard Industrial Classification (ISIC) of economic activities, generally used by national statistical agencies in most countries, and FAO (2010). FAO (2010) has lately started to also include rubber in its forest resource assessments, as old not-so-productive rubber stands are being increasingly chipped for energy-wood. $\frac{3}{3}$

The main species focus is on eucalyptus and pine: the two fast-growth main commercial plantation species used in pulp making. ${ }^{4}$ Some other similar trees are also surveyed, such as acacia, and all planted forests are included in the statistical section illustrating where and what is planted across the globe.

Timber products are still mostly extracted from natural or modified natural forests, but the share of plantations is increasing fast. Plantations provided in 2001 some 35 percent of the globally harvested wood (UNEP 2012). Since then the plantation share has increased as plantations have grown while the total forestry area has not (UNEP 2012). Considering this global importance, general discussion on plantations has been remarkably absent, although there is a sizable specialist literature as I will show.

\section{Conceptual framework}

Besides being a review, this contribution aims to provide a new analysis on the role of political and spatial causalities in capitalist expansion. I use Polanyi's (2001) study on the commodification of nature, human beings and market transactions (into land, labour and money, respectively) as an underlying political economy framework to explore how different capitalist systems are being established. I merge Polanyi's notion of commodification of land and labour as the principal driver in the development of capitalism with a Bourdiean spatial analysis. This allows developing an understanding of the causal dynamics between changes in social, symbolic and territorial space. These theories are used to explain the causes, variation (different styles and paces of expansion) and impacts of TPs in different contextual dynamics.

\section{Class relations, commodification and capitalism}

I will explore how power and class relations are tied to the changes in the control of different types of space (via establishment of TPs). I adopt Bourdieu's (1990, 1991, 1998) conceptualization of capital and space, and Wright's (2005) definition of class relations as social relations of production and exploitation. Wright ( $\underline{2005})$ argues that class relations exist when there is inequality in the distribution of rights and powers with respect to deployment of productive assets (labour power and/ or means of production) in production. Exploitative class relations are fundamentally spatial and 'this spatial organization is critical to understanding the nature of uneven development' (Gidwani 2009, 98). I will couple Wright's $(\underline{2005}, 14)$ neo-M arxist analysis of class relations as 'unequal rights and powers of people over economically relevant assets' with a Polanyian and Bourdiean analysis of land commoditization and land use change processes. It has not been common in peasant studies or in political economy to utilize Bourdieu's theories on spatial changes (in symbolic, social and territorial spaces) to explain the expansion of capitalism and exploitation.

In terms of Bourdieu (1991), the turning of land into capital and people into labour signifies that new power and thus power relations have been created into a space where such relations did not exist before. Following 
Wright's (2005) conceptualization of class, TP expansion creates class relations into spaces that did not have class as a key differentiator of social space. In line, M cCarthy (2010) makes the important note that sometimes inclusion and incorporation into expanding plantation economies even as capitalist producers have adverse consequences for those incorporated, and that a better option would be to not participate in the transformation. Although exploitation might not always be the case, as some TP or oil palm expansion might be beneficial for the locals, there's still a need to include the study of resistance, as, according to M cCarthy (2010, 847), change to better developmental outcomes may require building 'coalitions working across state and civil society to develop the capacity to reduce abuse and corruption, and to exert the pressure required to hold the state accountable'. However, following Bourdieu $(\underline{1990}, 138)$, before there can be resistance based on class conflict, symbolic processes must first emerge in which the social actors identify themselves and their adversaries, as well as the interests that can form the object of conflict. I will hereafter analyse the role of contention and the construction of knowledge by discourses seeking legitimization for particular land use change. Shiva and Bandyopadhyay (1985), Scott (1998) and Kröger (2011, 2012a) have already provided such symbolic analysis on the political-developmental-cultural dimensions underlying TPs, and I will continue with this line of inquiry. Next, I will introduce a new conceptual distinction on the different types of tree plantations that are expanded. This conceptualization of TPs into sub-categories allows for a more nuanced political economy of the transformations that different agents expanding or resisting TPs cause.

\section{Agency, space and power}

I will analyse the expansion of non-edible tree species cultivated in either (1) industrial large-scale forestry plantations of hundreds of hectares contractually controlled or owned by corporations (ITPs), or (2) small plots of a few hectares in maximum size by rural households (smallholder-based forestry plantations, STPs). $\stackrel{5}{\text { Besides }}$ ITPs and STPs, there are also public TPs planted and controlled by governments to generate benefits to the general public (for example, according to Rudel et al. 2005, in China most TPs are these, established to provide general environmental services and distributing benefits widely). There are also community-controlled TPs, distributing benefits equally to the community members. Others have introduced different conceptualizations, for other analytical purposes. ${ }^{6}$

This four-fold typology of plantations is built for studying agency, for identifying the social actors controlling space and divisions and relations between these. The analysis of control is based on probing the distribution of productive resources and accumulating capital surplus in TP expansion. If a publicly owned TP is large-scale and serves state capital interests (e.g. a public pulp venture), it falls under the ITP and not the public TP category. Many so-called community TPs are not actually controlled by villagers: for example, according to Karumbidza (2005), the expansion of community plantings is the current industry strategy for increasing the area of timber plantations in South Africa. In India, most 'community TPs' under the joint forest management scheme were not jointly managed at all, but a form of state (elite) enclosure of community lands (Gopalakrishnan 2012). These and other reasons render many community and public TPs as disguised forms of ITP expansion. Real public and community TPs did not surface as central in the review of data, although in some areas they are important. Thus, their relation to ITPS and STPs is discussed briefly.

Besides these TP categories there is of course also the option of no-TP land use, which may or may not involve resistance to TPs. ${ }^{\underline{ }}$ Resistance to expansion pressure is defined as those responses whereby people do not 
select a strategy of (loose or tight) incorporation into the TP business (e.g. by outgrower farming), or conflict avoidance (e.g. by silently fleeing from the site of convulsion), but where they fight (violently or non-violently, visibly or silently) to defend their autonomy, to retain or increase their control over territorial, social and symbolic space. This conceptualization of resistance and power relations draws on Scott $(\underline{2009}, 209)$ and Bourdieu (1991).

To explain social phenomena, one has to consider the agents, the division of social fields, and the interests and interactions these agents and fields have, be they conflict, competition or cooperation (Bourdieu 1998, 57). For example, the effectiveness of the TP land buyers, renters, leasers and outright stealers depends on the power or lack of power of the alternative approaches to organize the social space. I use Bourdieu's analytical tools to study how the structure and positioning of agents and changes in society always take place as simultaneous, relational shifts and transformations in the social, symbolic and physical spaces. Building on Bourdieu, I make a theoretical claim that if something happens in the physical space, this change must come with equal, correlated changes in the social and the symbolic spaces of the area in question. For example, when a plantation is established, the territorial change must correlate, now or later, with changes in the social and symbolic spaces. Otherwise the plantation activity cannot continue existing. If the social capital of those proplanting is diminished, their power to expand plantations becomes lesser. Likewise, if their symbolic power is diminished, i.e. their honour, their classification as agents of rightful, merit-based or natural development is questioned, shattered and brought into light as a fabrication that is actually based on the control of greater amounts of social, economic and/or cultural capital than those from whom space is taken, then their power to expand plantations becomes lesser. ${ }^{-}$If the total amount of capital of those resisting TPs is made greater by strategies that change the division of spaces, then plantations do not expand.

The merging of Bourdiean concepts to Polanyian and neo-M arxist class analysis allows for considering particularly the role of symbolic capital and power in landscape transformations and commodification processes that create capitalism. I will show how extractive investments come with a change not only in the territorial space but also in the local social space by involving the creation of landlessness in many cases and exclusion of alternative uses in most cases and, in the symbolic space, producing a pro-exploitation investment policy. I will use the Bourdiean class analysis to illustrate, for example, how elites have created the symbolic capital for the expansion of ITPs by framing swidden agriculture practitioners or rural communities as developmentally backward, and TP expansion as a positive developmental scheme that is promoted not by selfinterest but by a basis of goodwill and greater understanding of development by those pushing ITPs.

I use an incorporated comparative analysis (M cM ichael 1992) as an underlying frame to organize the accounts of different but globally and temporally connected structural and institutional settings, schemes and actor dynamics where plantations expand. I utilize M cM ichael's method to compare the multiple instances of TPs as products of a continuously evolving process in and across time (e.g. the instances of emergence of TPs in the nineteenth century; the recent growth of outgrowing and STPs; and the creation of ever-more intensive ITPs by genetic manipulation). I use also the singular form of incorporated comparison that analyses the multiple territories across space that experience differently singular world historic conjunctures (such as the post-World War II green revolution paradigm, post-1990 neoliberal new world order and the late emergence of the new 'green economy'). I will demonstrate by historicization how these global pro-ITP agendas have expanded when faced with different political agencies. 
Changes during the past decades on where TPs are located and what they have been conceived to be are first discussed. Then the roles of multilateral organizations, governments, companies and civil society are explored, in an analysis of the political causalities which have been found to explain the expansion. After this I will delve more deeply into the role of different spatial changes in influencing the way the expansion takes place. The destiny of those not needed in the TP expansion is discussed. Finally, a section analyses the likely future trajectory of this deepening capitalist process through exploration of the latest changes in the commoditization drive.

\section{Where are tree plantations located and what are they?}

Reliable statistics on plantation coverage are difficult to come by, as different entities use different conceptualizations of forest and plantations, and the field is evolving rapidly and with unsatisfactory monitoring. The United Nations (UN)'s FAO Forestry division maintains one of the most extensive databases, which is nevertheless problematic in many ways. The FAO (n.d.) itself admits that 'consistent definitions and reliable data have proven problematic in quantifying plantation forests or planted forest resources in both industrialized and developing countries'. Yet the FAO data is useful, if used for the purposes for which it is suited, and accompanied by other bodies of data (e.g. CIFOR, the Center for International Forestry Research, publications). When using the FAO data, one should keep in mind these contain consistent geographical patterns of data discrepancy and reporting, which are also political. FAO has been and continues to be a key actor pushing for TP, particularly ITP, expansion (Peluso and Vandergeest 2001), besides offering data. ${ }^{\underline{9}}$

Conceptualization differences produce incomparability in databases. FAO, the United Nations Environment Programme (UNEP) and other UN bodies talk about 'forest plantations' or 'planted forests'. 10 The FAO gets its data from governments, which use industry associations' figures (for example, in the case of Brazil, FAO uses data from ABRAF, the Brazilian Association of Planted Forest Producers). This is a problem, as governments, often close to companies, can be keen to hide the extent of tree plantations, and exaggerate the extent of natural forests, or do not offer data to the FAO for whatever reason. Data is both missed and misrepresented. NGOs claim that the real extent of plantation expansion is higher than those presented by governments and thus also the FAO.

This said, the following FAO (2011) table on 'planted forests' should not be read as the final word. Yet, the table indicates that plantations - broadly understood, understood as FAO understands them - have expanded dramatically between 1990 and 2010 .

The table indicates that global expansion has been 48.1 percent between 1990 and 2010. M exico has seen a whopping 815 percent increase between 1990 and 2010 and has now 3.2 million hectares of FAO-defined plantations (FAO 2011, 25). ${ }^{11}$ Alongside North America, South America (67 percent increase) and Asia and the Pacific (61.6 percent increase) were the two main areas of dramatic, above-average plantation expansion. In the Near East, TPs expanded by 49.5 percent. $\stackrel{12}{ }$ Europe was an exception for FAO; plantations were expanded by only 12.8 percent. The rest of the regions in the table experienced plantation expansion of 30-40 percent between 1990 and 2010. The bird's-eye view afforded by Table 1 shows that plantation expansion is a major issue. 
Table 1. 'Planted forest' expansion between 1990 and 2010 by regions, in millions of hectares.

$\begin{array}{llll} & \mathbf{1 9 9 0} & \mathbf{2 0 1 0} & \text { Change \%, 1990-2010 } \\ \text { Africa } & 11.663 & 15.409 & 32.1 \\ \text { Asia and the Pacific } & 74.163 & 119.884 & 61.6 \\ \text { Russian Federation } & 12.651 & 16.991 & 34.3 \\ \text { Europe } & 46.395 & 52.327 & 12.8 \\ \text { Caribbean } & 0.391 & 0.547 & 39.9 \\ \text { Central America } & 0.445 & 0.584 & 31.2 \\ \text { South America } & 8.276 & 13.821 & 67.0 \\ \text { Near East (excluding N. Africa) } & 4.677 & 6.991 & 49.5 \\ \text { Canada } & 1.357 & 8.963 & 560.5 \\ \text { M exico } & 0.35 & 3.203 & 815.1 \\ \text { USA } & 17.938 & 25.363 & 41.4 \\ \text { World } & \mathbf{1 7 8 . 3 0 7} & \mathbf{2 6 4 . 0 8 4} & \mathbf{4 8 . 1}\end{array}$

The official statistics on global forests illustrate how plantations expand while primary forests and other naturally regenerated forests decrease or retain their size. For example, according to Canada's forest resource assessment, its forest area did not change at all between 1990 and 2010 (remaining at 310.13 million hectares), but the area covered by planted forests increased by 560.5 percent to about 9 million hectares. Canada's alleged no-change in forest area is also a case in point to get alarmed about the quality and extent of TP data management. Much more fieldwork observation, and pruning, specification and systematization of the data have to be done by FAO, governments and others to provide more accurate statistics.

\section{Main divergences and commonalities in expansion trajectories}

Diverse landscapes have been turned into uniform, single-species tree plantations (Patterson and Hoalst-Pullen 2011). A study in New Zealand found that because forestry is a more intensive and higher-demand land use than pasture, tree plantations push the second-priority pasture and agriculture use to peripheries (Nagashima et al. 2002). According to the reviewed publications, this dynamic applies in many other contexts, including Latin America, but there are some important variations to what type of land use is replaced or being pushed to peripheries. What is clear is that the expansion does not take place in a vacuum, but in the contexts of (typically rural) cultural and human ecological mosaics. In Australia, dramatic TP growth between 1997 and 
2009 (from 1.2 to 2 million hectares) represents a radical change in rural landscape character and economic activity, with food-producing family farms turned into corporate ITPs (Stewart et al. 2011). Similar land use changes occur in ITP expansion frontiers across the globe. M eanwhile, the countries in the Bolivarian Alliance for the Peoples of Our America (ALBA) (field research, 2004-2011), Thailand (Barney 2004), Vietnam (Sikor 2012) and Finland (Finnish Forest Association 2012) have barred an expansion of markedly corporate forestry. Instead, STPs or public ITPs have been created in some of these countries, or they have relied on natural or semi-natural forest growth. ITPs have been the mainstay in many countries, most markedly in Brazil, Uruguay, Chile, Indonesia and M ozambique.

In South America, the current expansion pace is at 500,000 ha per year (Jobbágy et al. 2012) and this is increasing. In Africa, the rise may be even more dramatic than in South America: for example, Pöyry Forest Consulting - a leading promulgator of ITP expansion - has argued that by 2022, Africa will be the centre of TP expansion globally (Kröger 2013c). If resistance does not stop this expansion, Africa will foreseeably see a wide spectrum of tree plantation types and uses. These include ecosystem services plantations such as 'carbon sinks' operating on the REDD+ markets and under development cooperation agendas (Overbeek et al. 2012), energy plantations, pulp projects integrated with plantations and mills, and other biomass ventures. In fact this is already happening.

Tree plantations are eyed by some to become major carbon sequesterers. There is a large debate and disagreement over the types of activities in which this occurs (see e.g. Lohmann 1999). The straightforward conceptualization of TPs as 'carbon sinks' by the industry is contentious. The carbon is not 'sunk' into the trees for a long enough time for ITPs to receive the tag of carbon storage, argue the critics. Pulpwood plantations are harvested after a few years. Then the wood is pulped and the pulp turned to paper and cardboard, which is soon consumed and mostly burned. Carbon thus returns quickly to the atmosphere. For TPs to be characterizable as carbon sinks, Böttcher and Lindner (2010) argue plantations should last at least a few decades and the sequestered carbon should then be protected by conservation measures. In sum, it is hard to argue that a fast-wood TP would be a carbon sink.

The financing structures of investment vary between countries. For example, in Brazil, ITPs and pulp projects are funded largely by the national development bank BNDES, The Brazilian Development Bank, and the pension funds (Kröger 2012a). It is worth mentioning that all around pension and mutual funds, even Church funds (such as the Swedish Church involvement in M ozambique ITP investment, see Overbeek et al. 2012), are becoming key forestry capitalists. National funding by rising economies such as the BRICS countries (Brazil, Russia, India, China and South Africa) and Indonesia is bound to play an even more crucial role in the future than now. This will influence politics, as the absence of international involvement (e.g. of the World Bank, traditionally high in TP investment, see Carrere and Lohmann 1996) offers different investment guidelines. Meanwhile, corporate investment is also increasing. The global South is also attracting new timberland investment by portfolio funds seeking diversification.

There is a global division of power, visible in the unequal distribution of export-TPs into the South, and the higher number of added-value capital investments in the North and China. M ore of the world's added-value timber manufacturing plants, including paper mills, have been heavily locating in China. This has already put China into a very different position in global forestry capitalism's division of labour and revenues than the 
commodity-producing countries of Brazil or Uruguay, for example. According to RISI (2011), the Chinese paper company Nine Dragons Paper Holdings was the world's seventh largest in 2010 in terms of paper output (7.3 million tons). In fact, China was already in 2010 the world's largest paper producer: Northern countries represented 53 percent of global production and this figure has been dropping (Swedish Forest Industries Association 2010). The South American companies and countries are not even close to the Chinese and Northern paper production figures, but focus on pulp production. There is huge TP expansion also in China: eucalyptus ITPs have expanded from 1.7 million ha in 2006 to 3.13 million ha in 2010 (Global Wood Trade Network 2011). In many cases, this expansion has been carried out by dramatic suppression of human rights and even killings of those who speak against this land grab (Ping and Nielsen 2010).

\section{What political-economic causalities explain the expansion?}

\section{A corporate or smallholder-driven process?}

The global expansion has been driven more clearly by corporations and public TPs than by smallholders. Yet Sikor $(\underline{2012}, 1078)$, citing evidence from the FAO, claims that 'smallholders have driven the dramatic expansion of tree plantations worldwide' between 1990 and 2005, allegedly owning 32 percent of TPs by 2005. Del Lungo et al.'s (2006) data is cited as a reference for the smallholder-centrality claim in Sikor (2012). Del Lungo et al. consider also community and public TPs as 'smallholder plantations'; but the control of these is not in individual family hands, but in the hands of a community group or state actors controlling public lands. Therefore, representing the global rise as driven by smallholders may be stretching the STP concept, and the claim that TP expansion would be driven mostly by smallholders seems incorrect. Also, smallholder and public TPs have been important ways for TP expansion, but such expansion has focused on particular countries. The global dominance of ITPS as key drivers becomes very clear if only exotic species TPs are considered - whose composition per TPs across countries are given by the FAO (2010) - and even clearer if the 'planted seminatural forests' with under-vegetation, non-timber forest products, and looking like forests, are left outside the definition of TP. $\underline{13}$

\section{State capitalism and exploitation}

States have been central everywhere TPs have expanded, the whole TP business originating from German state forestry officials' attempts to boost timber yields in the nineteenth century (Scott 1998). In this sense, both the corporate and smallholder capitalist expansions of TPs have a crucial state capitalist element in them. This state capitalism - or more precisely, oligarchic government-elite capitalist class interest - behind TPs becomes even clearer when looking at the role of multinational organizations such as FAO or the World Bank, controlled by governments, in boosting TPs across the globe since the 1950s (Carrere and Lohmann 1996). M ost governments eased the corporate-driven globalization process from the beginning with subsidies to ITPs (e.g. Bull et al. 2006). Pro-ITP legislative frameworks were drafted: governments weakened environmental regulation and offered elite-benefiting territorial titling (e.g. du M onceau 2008). Furthermore, if governments shared an electoral-institutional-ideological alliance with the industry (Kröger 2013a), they boosted the ITP expansion by liberalizing financial markets (Stewart et al. 2011). Concomitantly, violent methods such as dispossession were used ( $M$ archak 1995). Forced territorial transformation by land grabbing was coupled with discourses promulgating the ideology of TPs and their promoters' (foresters') superior developmental role in 
comparison to existing land users, who were driven into a lower-class social position by the commoditization of their land, forests and labour.

According to the literature above, the first wave of expansion in the 1970s-1980s was the most violent and socio-environmentally destructive. At this time, the dictatorships, for example in Indonesia, Brazil and Chile, rooted the corporate ITP model to their countries with an iron fist. Expansion still takes place by violence necessary for enclosing lands, ITPs continuing to expand primarily via accumulation by dispossession (see Kröger 2012a for an illustration of this in Brazil).

\section{The role of resistance}

Although the main reasons for TP expansion are placed on the pushing side, resistance has been found to also play a role. Resistance can take many forms, being for example visible or silent. Examples of the former are publicity-seeking mass protests where trees are cut. Examples of the latter are the numerous instances where unhappy locals seek to compensate for their loss of land to ITPs or too-low remuneration for land lease by covertly burning and cutting trees. These actions are ubiquitous, for example in Stora Enso's Guangxi pulp project in Southern China. According to an internal company report (Yang 2011), the time of local company executives often goes into battling against illegal logging and fires set purposely. These acts of invisible resistance try to compensate for the too-low rents paid by the company. According to the company report, the low compensation for land causes much of the grievances and acts of resistance (Yang 2011).

Different types of resistance movements to TP expansion exist throughout the globe: their mobilization has fostered a multitude of TP conflicts. Gerber (2010) found that by far the most common resisters are neighbouring impacted rural populations such as smallholders, landless labourers and traditional rural communities; a finding found also in a more detailed study of Brazil (Kröger 2011). NGOs of all levels ranging from local to international groups are also involved in the resistance networks (Kröger and Nylund 2012). Although sharing a criticism of ITPS, the resistance is not a united front as there are tensions on the proposed alternatives and other issues (Gerber 2010).

In some places, resistance has become a major force in impacting where expansion takes place (Kröger 2011). This has happened if the resistance has used multiple strategies simultaneously, including organizing and politicizing a movement, targeted campaigning, protesting, networking and embedding the state whilst retaining autonomy (Kröger 2011). $\stackrel{14}{ }$ By these strategies that build social, economic and other types of capital, movements have gained power, visible in the way they have managed to carve out for themselves autonomous and alternative territorial space in the same landscape desired by the industry for ITP expansion.

Protests have convinced governments to intervene and distribute land rights to communities. For example, in Brazil's Espírito Santo the indigenous communities gained a major victory in 2007-2008 by regaining 18,000 hectares of eucalyptus lands occupied by Aracruz. This outcome was a result of the indigenous people replicating the radical strategies of contention that the MST, The Brazilian Landless Rural Workers' M ovement, had pioneered (Kröger 2011). Since this outcome, the main goal of the resistance front in the state, 'the struggles against Fibria have diminished a lot' (interview with Ednalva Gomes, MST coordinator in Espírito Santo, 22 April 2013, Helsinki). 


\section{The interplay of national and international political dynamics}

Movements and corporations are in a dynamic interplay to steer state policies to their own ends. The outcomes of these national political games have international ramifications. An early example is Thailand in the 1980s and early 1990s (Hall 2002). In Thailand in 1992, militarized expansion of eucalyptus plantations was discontinued because of resistance, retaining smallholder farmers' land control. Expansion would have required the displacement of 250,000 families. Instead, paper firms from Japan withdrew from Thailand and invested in Australia. Thai firms responded to the toughening political and regulatory context by investing in neighbouring countries with lower levels of regulation and resistance (Hall 2002). The 1992 Re-Afforestation Act, an outcome of increasingly strong eucalyptus activism, led to a complete halt on new corporate plantation (ITP) concessions since 1992 (Barney 2004).

The outcome of industry moves and subsequent expansion site selection are thus based on state support and societal resistance responses. For example, Finnish paper companies started to avoid Indonesia after global criticism by powerful NGOs of environmental destruction in the 1990s. Instead they shifted focus to South America, particularly Uruguay (interview with Ricardo Carrere, WRM coordinator, 9 June 2005, Helsinki). Uruguay provided a less conflictive setting than the more productive, yet more resistance orientated, context of many Brazilian states (Kröger 2011).

When faced with resistance capable of challenging land control, the uncertainty about long-term corporate access to land is a major concern for ITP promoters. In my interviews for this study, executives gave more importance to the resistance than movement leaders themselves. When resistance is too strong, plantation firms choose instead to expand in political environments with greater land access security and less dense rural populations, such as in Australia and Uruguay. Hall (2002), studying ITPs as pollution havens, notes that the main reason for selecting political systems where corporate land tenure is protected strongly is not merely land control per se. More important is that greater security of tenure raises the likelihood of environmental damage, environmental damage being a required outcome for establishing ITPs for Hall (2002). Low population density is often understood to diminish the prospects and strength of resistance over water use and pollution issues by impacted populations. Evidence from a comparative study of expansion in Brazil (Kröger 2012a), however, suggests that ITP expansion even in relatively high rural density contexts has been rapid and massive, given that large land masses have been appropriated easily and cheaply. In this sense, the political processes which have allowed for a cheap and easy appropriation of land remain key explainers of where expansion takes place. Natural conditions influence this only insofar as a piece of land is considered suitable for TP expansion by a social agent.

Low land prices, supportive state policies and incentives remain the key reasons for plantation location, particularly in contexts of poorly organized resistance. This is because TP expansion has been mostly driven by corporate-government elites whose model of development is based on accumulation by dispossession. If resistance does not challenge the development, this commoditization drive ends up replacing a mosaic of rural economic-cultural relations by a capitalist class relation, whose visible signs are the stand of trees extending to the horizon and the accompanying discourses glorifying the investment, as I will discuss next.

\section{How do spatial changes influence the socio-environmental impacts?}




\section{'Political forests': the centrality of land control in ITPs}

The expansion of TPs has happened by the creation of pro-TP territorial, social and symbolic spaces. Discourses are used to create the symbolic space for TPs, to turn them into a political tool of land control that is hidden by their presentation as non-political, solely positive-impact tools of development. The positive aesthetic valuations of TPs, if rooted among decision-makers and society, accrue honour, symbolic capital, to the social actors expanding them. This symbolic capital is necessary to retain the legitimacy of TP expansion.

The Southeast Asian expansion, where most current plantation areas were previously primary forests and spaces under swidden agriculture, illustrates that the modifying of existing social, territorial and symbolic relations has been necessary for establishing TPs. Symbolically, swidden agriculture was first framed as a developmentally harmful and negative way of using land, which had to be modernized (Fox et al. 2009). TPs were framed as modern and effective ways of resolving the swidden agriculture problem and to modernize the nations. According to Fox et al. (2009), the plantation expansion in Southeast Asia replacing swidden in natural forest had a double impact: plantations lessened the ability to produce own food by swidden cultivation, and created more divided social spaces by increasing the power of those able to expand landholding via government-backed tree planting replacing the swidden. The expansion of swifting cultivation had to be tamed, framed as a negative development so that plantations could be expanded. For example, in M alaysia's Sarawak state, swidden expansion was blocked to reserve land for logging and plantations (Fox et al. 2009).

Peluso and Vandergeest $(2001,762)$ introduce the helpful concept of 'political forests', a term by which they emphasize how 'forests' are politically constructed and might not even have forest in them. To increase the capital of some, rather than to increase or preserve forests, has been the main goal. Peluso and Vandergeest (2001) argue 'forest' demarcation has served more the political needs of land control than the ecological concerns of forest preservation or use, with this notion applying globally. In fact, tree monocultures have often replaced high-biodiversity natural forests, although officially expanding on 'degraded' lands (Sargent and Bass 1992).

These cases support the theoretical hypothesis (that builds on Bourdieu's concepts) I made in the beginning that different spatial changes (territorial, social, symbolic) follow each other sooner or later. The cases furthermore suggest that when landscapes and symbolic spaces are changed simultaneously, the goal of changing social space may be achieved more securely. The goal of social change to boost the economic position of elites by creating capitalism, but also the goal of resisting against exploitative socio-economic relations, is best achieved by united or concomitant practices changing symbolic-territorial space.

\section{Rent bases for capitalist elites}

The elites have gained most from this consolidation of 'degraded' forests under state control, in the form of land concessions, subsidies and rents, argue Barr and Sayer (2012) in a discussion of the Asia-Pacific. Timber provides rents for the elites in a similar way to oil (Ross 2001). The elites have directed the ITP-created timber rents to political and economic activities allowing even greater expansion of the rent-yielding area (thus further expanding ITPs) and power outside the forestry sector. The rent incentive has led in Indonesia to what Barr and Sayer (2012) call perverse outcomes, wherein naturally or already-commercially valuable forest or timberland is destroyed and replaced with ITPs. In a vicious circle, accumulated capital has been invested in too-large pulp 
mills, 'requiring' larger rent bases of ITPs to feed them (Obidzinski and Dermawan 2010). The political consequence of luring governments and international investors into building too-large pulp mills (as no pulp mill is built by the companies operating them, due to their high capital-intensiveness, see Kröger 2013a) has been the creation of a larger capitalist interest group which wants to see that their investment will pay itself back. The most profitable way (in the short run) to secure this has been to expand plantations as close to the mills as possible, as extensively as possible. This use of technology as a hostage and a political tool has allowed for a faster and more ruthless exploitation and expansion, as a wider base of those with interests creates a larger social group that can manipulate the symbolic and territorial spaces more effectively.

\section{The commodification of labour by TP expansion: a tool of impoverishment?}

In her study on labour relation transformation in land grabs, Li (2011) argues that industrial plantations have long been a strategic corporate tool of impoverishment, which turns locals into a population that serves as a 'surplus' labour supply for them. M ultinational development agencies and governments have supported this transition by urging those unable to compete against industrial plantations to retire from the agricultural sector (Li 2011). These deliberate manoeuvres to form a 'surplus' population via impoverishing them, i.e. making them unable to compete against new large commercial farms or robbing their land, is a key issue also in the current land grabbing, of which ITPs form a part (Kröger 2013a). This commodification of human beings as 'surplus labour' is one of the key mechanisms in creating capitalism that Polanyi (2001) described. It is often accompanied by the financialization of commercial transactions (in the case of TPs by tying people into global timber markets instead of relying on their own agricultural produce).

The literature on social relations (including conflict) between TP owners and labour is larger than the scholarship on TP-impacted community relations (Gerber and Veuthey 2010). The people in TP investment areas tend to suffer from precarious working conditions (WRM 2007). After plantations they find themselves bereft of their former cultural sites as well as memories (Karumbidza 2005). Those most severely impacted by both ITP and STP expansion are poor rural women who are frequently not even smallholders (M cElwee 2009). The division of labour and the security situation has typically changed for the worse for women, as former food production or hunting grounds have been turned into TPs employing mostly migrant men (Ferreira 2009).

Forestry capital may come in search of land not labour, or both land and labour (see Clapp 1998 for a study of Chile in this respect). ITPs are the key to assure both goals if the displaced 'surplus' populations do not revolt. In Brazil, people displaced by corporate plantation expansion have formed camps and started to work as wage workers for the plantations (Kröger 2013a), while in Laos, companies have in-built planning for such camps on future plantations, to get access to and control cheap labour close to land (Baird 2011). In both cases there has also been resistance to incorporation, in the form of organized (i.e. via social movements such as the MST) and spontaneous (i.e. by neighbouring communities' sudden land occupations) protests, often by the same people that have had no option other than to work for those who dispossessed them. The change in the control and use of space has been dramatic and led to abrupt changes in lifestyles. In Laos, indigenous people living in forests have had to shift from an economy where they produce 90 percent of their own food and buy only 10 percent, to an economy in which they must buy 90 percent of their own food and can gather only 10 percent (Baird 2011). This has led to a violent process of proletarianization, in which land is turned into capital and people into labour, according to Baird (2011). 
Companies are looking more for land and less for labour: land is becoming ever more scarce, while the (precarious) 'surplus' population grows (Li 2011). This is because the mechanization drive diminishes the need for labour all the time. The jobs offered by TP expansion depend on the TP investment type. If the trees are destined for large-scale pulp mills, jobs have been more precarious and temporary than in construction-wood destined forestry areas, studies in Brazil (Gonçalves 2001) and Uruguay (Carámbula et al. 2011) suggest. In Brazil, companies force forestry workers to join 'cooperatives' to avoid hiring them under employee protection laws: Veracel has now almost 2000 labour law violation suits filed by workers and prosecutors (fieldwork, 2004-2011, Harari 2013). The increased power of global forestry capitalists versus labour has decreased the bargaining power and autonomy of those down the supply chain (Dauvergne and Lister 2011).

\section{Deep commodification of land by irreversible enclosures}

The main goal and driver of capitalist development is the commoditization of nature, which has been pursued by taking under elite control as tightly as possible as large land areas as possible. Companies are relying ever more on large-scale land leases from governments to secure an ITP base. Many have criticized leases as undemocratic and non-transparent land grabbing. Given the demand, ITPs have been given concessions so fast that few state institutions can monitor or regulate them. The institutional arrangements for dealing with the rapid pace of plantation expansion have remained very inadequate even in a country such as Australia (M ercer and Underwood 2002). In Laos, the 'exponential growth of the granting of land concessions' has led to the feeling that the government has 'lost control of the process' (Hanssen 2007). M ost worryingly, according to researchers, the conversion of land to TPs is irreversible, e.g. in Uruguay (Carámbula et al. 2011) and Chile (Nahuelhual et al. 2012). In Chile, the conversion to plantation forestry is absolute and irreversible: once established, corporate areas are required to permanently remain under plantation forestry by Chile's law DL 701 (Nahuelhual et al. 2012). In U ruguay, the government has given very strict investor guarantees to foreign companies such as Stora Enso, assuring that they will receive land for establishing a sufficient number of plantations for the needs of their pulp mill (Bacchetta 2012).

\section{The conditions under which TPs may work against exploitation}

The conditions under which pulp plantations may complement, rather than threaten, livelihoods of local communities are extremely limited, argue Pirard and Mayer (2009) in a study of Indonesia. They claim that at least one fifth of land should be left to intensified local agriculture and agroforestry instead of plantations. Company operations should be carried over with care and constant consultation with impacted populations, giving priority to local employment. The minimum conditions include also careful determination of plantation sites and transparency in licensing concessions. Local and customary rights must be recognized. The abovementioned minimum conditions that Pirard and M ayer (2009) argue are essential for the ITPs and largescale pulpwood TPs to support local livelihoods are very tight, in fact, so tight that it might be impossible to fulfil them by ITPS.

Public and community TPs may not have any better developmental consequences than ITPs. According to Barr and Sayer (2012), the socially attuned forestry programs have excelled mostly just in theory until now. For example, in India, with a markedly more 'social' (i.e. public) than corporate forestry model, targets have not been met, and villagers have mostly been passive spectators of the raising of trees on their land (Saxena 1997, Kumar et al. 2000, cited in Barr and Sayer 2012). India is one of the most marked state plantation forestry 
examples: its plantation forestry was developed since the late 1970s by establishing TPs in villages. This has been typically done by force. Some argue that the 1988-created Joint Forest M anagement program did expand usufruct rights of villagers. But the same authors note that the spilling of economic benefits to the most marginalized community members depended on local power relations (Sekher 2001, Sarin 2003, Kumar et al. 2000, cited in Barr and Sayer 2012), such as gender and class cleavages. This watered down the process by creating more inequalities in land control both within the community and between the community and the state and outside elites. The program and whole TP trajectory in India has thus been called by critics the state elite's enclosure of community lands and labour (Gopalakrishnan 2012).

The developmental outcomes of plantations have depended on the existing power relations, i.e. the way the territorial and social spaces are divided, which defines the equality in the division of capital and gains. I will next study the different kinds of capitalist transformations that have taken place when STPs have been the main form of expansion.

\section{Smallholder versus industrial tree plantations}

STPs have been the main path of expansion in some areas. The reasons to establish STPs are many, but are driven in most contexts by the desire by corporations to alleviate risk and conflicts by incorporating smallholders into forestry (Pokorny et al. 2010). In some contexts, the aim may also be to draft socially- and/or environmentally-oriented policies, and seeking to diversify rural incomes and environmental services via STP promotion (Pokorny et al. 2010). Some see STPs as a developmental tool. Thailand is an often-cited STP'success' case. Contract eucalyptus farming on smallholders' lands has come to be the mainstay of fibre provision for Thailand's pulp industry after the late 1980s ITP-resistance success (Boulay and Tacconi 2012). Pulp mills are small in Thailand and there is real competition between them to secure fibre. Barney (2004) notes that about 65 percent of all eucalyptus in Thailand is cultivated by smallholders (over 30,000 households, with on average 5- 8 ha plantations). Establishment of ITPs has been made impossible in Thailand with the resistance against ITPs based also on environmental reasoning (Puntasen et al. 1992).

Tree planting may therefore also promise benefits to smallholders, besides the elites and corporations, although potentially it would undermine livelihood security (Barr and Sayer 2012) as subsistence food cultivation areas would turn into timber production. Leys and Vanclay $(\underline{2010})$ see potential in STPs if undertaken by people themselves, for example by forming cooperatives able to influence decision-making, particularly regarding sale prices. Non-oligarchic capitalism, based not on the commodification of labour but on boosting entrepreneurship and ownership or control of capital (including the commodified land) among the would-be labourers, can yield a less exploitative social space than ITP expansion.

Stable institutions, secure tenure and enabling policies are necessary preconditions for STPs to even potentially improve livelihoods, argue Kassa et al. (2011), in a detailed study of Ethiopia. In contrast to smallholder agriculture, STPs require typically much more capital and time, and produce less cash income (Pokorny et al. 2010). TPs are a long-term and specialized investment, requiring creation of technical skills and stronger property protection for the capital: the yields, even though they might be higher if trees are grown well, are realized only after many years. The TP areas are enclosed from other uses, creating a strong opportunity cost that is paid by all, not just the TP farmers. 
In many of the cases I observed, the TP outgrower contracts were made so tight and the land use change by companies who planted on outgrower lands was so harsh (destroying prior infrastructures, environment and landscapes) that it was hard for outgrowers to leave the schemes and return to food production or other land uses. The bondage in outgrower schemes seems to depend on the contract and ensuing irreversibility of landscaping. The deeper the commodification of land as suitable only into TP production, the more exploitative is the ensuing capitalist relation likely to be. This promotes the Polanyian hypothesis on the centrality of deep and irreversible land enclosures as drivers of capitalism (of the oligarchic variety).

In most cases, the environment suffers because of TPs even though smallholders would gain economically. The Vietnamese STP program focused on establishing tree plantations rather than supporting natural regeneration (M cElwee 2009), which explains why important sources of non-timber forest products have been replaced with monocrop exotic TPs. The most vulnerable populations have been negatively impacted, even though some other smallholders would have gained from the conversion of supposedly 'bare' hills, composed of shrubs, into tree plantations (M cElwee 2009). Thus, failures in general livelihood provision in STPs are linked to environmental degradation, which has taken place also in the 'success' contexts (M cElwee 2009). This suggests that even though a smallholder capitalist system based on TPs would be created, with equality among TP producers, this system of capitalist creation often still depends on commodification of nature and labour of those outside of gains.

Following the conceptualization of Wright ( $\underline{2005}$ ), class relations have been created between the new smallholder-capitalists and the landless surplus population. STPs targeted at the poor in Vietnam have often disadvantaged the poorest as these developmental schemes have been embedded in unequal local power relations (Sikor and Nguyen 2007), although the situation might have improved in recent years (Sikor 2012). The livelihoods of those not earning tenure have actually been damaged by smallholder tenure as they have become even poorer or marginalized (Barr and Sayer 2012) in terms of land control. M cElwee (2009) argues that exotic tree plantations targeting individual households in Vietnam have supplied often only low-quality and low-value timber and fuelwood, and suggests that natural regeneration targeting villages would be a better forest policy by supplying a diversity of forest products. This would have the added benefit of avoiding the destruction of non-wood forest resource exploitation, benefiting particularly those not controlling the timber stand but able to harness the non-wood products (a right varying across tenure systems).

Often the value of non-wood forest products is higher than the timber value. Yet, in TPs, particularly in ITPs, there is no mentionable amount of underbrush, mushrooms, fruits, berries or other non-wood bounty to collect. Timber is made the only capital, and yields incur to its controller. As the right to accumulate capital becomes more concentrated, by denying the access of others and even their possibility to harness the nature's (now-inexistent) bounty by intruding the fenced areas, inequalities can deepen at a multiplied pace.

In light of these studies and experiences, it is clear that STPS - outgrower or non-contractually-binding - are not the best way forward socially, economically or environmentally. In their excellent review of STP schemes, Pokorny et al. $(\underline{2010}, 161)$ claim that 'secondary forests, compared to plantations, have the potential to deliver environmental services of a higher quality at significantly lower costs'. As the potential of TPs for smallholders is limited and dangerous, growing single trees or focusing on natural regeneration are far better alternatives (Pokorny et al. 2010). This focus fixes simultaneously the social, economic and environmental pitfalls of TPs. In 
light of the theories used in this research, the reason for this avoidance of developmental pitfalls in the alternative development path (growing single trees or focusing on natural regeneration) is that the commodification of nature has not extended as far as in TPs, which means that (destructive) capitalism has not advanced as far (a Polanyian causal argument). In terms of Wright's (2005) theory on capitalism, this means that exploitation has not advanced as far, because the distribution of rights and powers with respect to deployment of productive assets is more equal (natural regeneration and single-tree growing requiring typically less specialization, allowing for a wider group of people to 'deploy' tree growth as a productive asset). In terms of a Bourdiean spatial analysis, the territorial space has not been changed via the introduction of STPs. The absence of transformation in one space (territorial) explains why change does not occur in the other spheres that explain developmental impacts (class differentiation in social space being a primary explainer of impoverishment and exploitation). These causalities can be further highlighted by the usual socioenvironmental transformations that TPs and particularly ITPs cause.

\section{Socio-environmental impacts}

The socio-environmental impacts of TP expansion have been examined extensively in the scholarly literature. While the studies referred to above focus more on the social impacts, another set of literature in the natural sciences has produced articles focusing more on the environmental impacts (whilst not forgetting the social connotations of these, which are inseparable).

Tree plantations typically cause severe damage to the soil, water flows and ecosystems (Jackson et al. 2005). TPs have a higher water use compared to pastures and agricultural crops, which is a main reason for local grievances by farmers (Stewart et al. 2011). Water usage by eucalyptus is dramatic and environmentally dangerous, particularly in plantations set in prior pasture or agriculture areas and managed under large-scale cutting practices (Jobbágy et al. 2012). Pine plantations increase evapotranspiration and decrease stream flow; pines are also invasive, impacting negatively on surface water runoff, grazing resources and biodiversity, and exacerbating the problem of wildfires (van Wilgen and Richardson 2012). The greatest possibility of negative trade-off between tree plantations and reduced water yields is in regions where water resources are threatened by decreased rates of precipitation (Jackson et al. 2005). Water use and pollution are the key concern of impacted populations both in the South and the global North, such as in Tasmania (Flaten 2011).

Forest destruction and loss of unique biodiversity (including also natural grasslands) has accompanied expansion (Little et al. 2009, 162). This drill has been permeated by capitalist cultural values that have clashed with non-capitalist values. According to Nahuelhual et al. (2012), TP expansion, for example in Chile, has been a direct cause of deforestation and biodiversity loss - felt primarily by the indigenous Mapuche people dispossessed of their ancient land and human ecology (interview with Mijael Carbone Queipul, leader of Alianza Territorial Mapuche, 19 October 2011, Helsinki). Queipul considers ITPs 'a silent extinction of the Mapuche', comparing native people with native plants and the companies and the state with exotic outsiders. 'We have not been so egoistic with our Mother Earth' as the companies or states, he argued, noting that Mapuche have their own sustainable, alternative economy and do not need TPs. Forestry capitalists promote exotic species monocultures for their greater yield in the accumulation of capital, whereas local populations not inside the symbolic and social system of 'scientific forestry' but with, for example, animistic socio- 
environmental practices eschew such purely economic actions, as they go against their livelihoods, social fabric and worldviews. $\underline{15}$

\section{The future: the likely outcomes of deepening global forestry capitalism}

In this final section, I will discuss why TPs continue to expand, and show how the forest industry is rapidly changing through the introduction of flex tree plantations. Fibre costs are the most essential element in paper and packaging cardboard manufacturing, a main destination of plantation trees (Spek 2006). Northern pulp and pulpwood is replaced by even cheaper TP-fibre and pulp from the South, thus offering larger profits. Global consumption has also increased: the increased packaging of forest products amongst others in card board or paper, typically thrown away as soon as the item is opened or used, has further increased demand (Dauvergne and Lister 2011). Industry mergers and neoliberal globalization coupled with high-profit ITPs have allowed for a new cycle of capital accumulation within the forest industry (Kröger 2013c). The returns are re-invested in further TP expansion, this territorial expansion being the core of the new cycle of accumulation (Kröger 2013c), and mergers. The corporate concentration of supply chain control has reduced system-wide production costs within global forestry capitalism (Dauvergne and Lister 2011).

In this setting, pulp companies from the South have risen to a prominent global position (e.g. Chile's CM PC and Arauco, Brazil's Fibria and Suzano: see Kröger 2012b for analysis of this rise). Yet, this does not mean that the North-South power balance based on the flow of too-cheap commodities to the North, damaging populations and nature in the Southern production areas, would have equalized the setting (see Bunker and Ciccantell $\underline{2005}$ for a general analysis on this). Even the South-South investment (e.g. from Chile to Brazil and Uruguay, Vietnam to M yanmar) is based on a model causing great socio-environmental damage in investment areas. Situating these areas as pulp or other commodity extraction areas within the global division of labour does not make the general North-South commodity flow less lopsided. What has happened, though, is that some Southern national cores (e.g. São Paulo) and oligarchic capitalist families and pension funds owning the new Southern forestry capital have been gaining leverage and windfall gains (Kröger $\underline{2012 b}$ ) as they have managed to secure preferential access to social, symbolic and territorial space in their domestic settings. This has happened at the cost of local populations and for the overall benefit of resource-importing global cores. The new Southern pulp giants (e.g. Fibria, CM PC) do not yet have the right or power to deploy the productive asset of a large pulp mill accompanied by ITPs to the global North, such as into the Nordic countries; but the contrary is true, signifying (in terms of Wright 2005) that an inter-capitalist class inequality still exists between the Northern and Southern producers.

ITPs are expanding because they are a powerful capitalist strategy of accumulation and control. This happens in a continuously evolving yet historically specific process of deepening forestry capitalism (Kröger 2013c). Changes in territorial practices have followed changes in the symbolic understanding of forests. At a deeper level, based on Bourdieu's $(\underline{1991}, \underline{1998})$ analytical framework, the expansion is explainable by the historical dynamics between agencies in different spaces.

\section{Surge of forestry capitalism and imperialism}

The capitalist forestry knowledge was created in eighteenth-century Germany, led by the desire to have sustained timber yields over an unlimited period. This led to the creation of forestry schools that trained 
'scientific foresters', seeing forests as sources of timber. This supported the creation of single-species tree plantations. After the Second World War, argue Vandergeest and Peluso (2006), the FAO became a central organization promulgating a type of Forestry Empire, which accompanied the older ideal German forestry model that replaced natural forests with managed timber stands ever since the nineteenth century. While TPS took the place of forests in the territorial space, they also uprooted 'forests' in symbolic spaces, as visible in the discourses of pro-TP politicians, capitalists and multinational organizations. These elites became very closely aligned in the post-Second World War global developmental paradigms of the green revolution and later neoliberal globalization and the new bio-economy of the present day. The formation of this new global social actor generated for it an unequal control over the social space shared with other forest- and now-TP-land definers, dwellers and users.

\section{Twilight of global resource scarcity, bio-economy and flex trees}

Land is currently valued as the base of new biologically produced commodities that are mired to replace the non-renewable resources that are running out. $\frac{16}{16}$ This emergent global 'bio-economy' will explain an evergreater part of future TP growth. The new policy of creating a 'green' capitalist economy is destroying forests while expanding TPs. The new Brazilian Forest Code approved in 2012 allows for the consideration of the conversion of 'degraded forest' (which might be primary forest) or recently logged primary or secondary forest into a tree plantation such as pulpwood eucalyptus as reforestation (Vidal 2012).

Another main reason for the prognosis of robust expansion is that plantations are becoming areas where 'flex trees' are planted. The forest industry is merging with other industries. Flex trees are the commodity consequence of merging inter-industry interests in the emerging green/bio-economy. Biomass in the same plantations can be used for pulp or energy, pulp prices largely determining the use of biomass until now in the case of Brazil (Fearnside 1998). Energy and other timbers uses become more prominent, while pulp will continue to be important. Pulp prices have soared in the past 15 years, and consequently there is a mill construction boom. $\stackrel{17}{ }$ For example, in Brazil, one 1.5-megaton pulp mill is projected to open each year until 2020. With many new large-scale pulp projects in the pipeline, overcapacity, along with slowing growth, can slow down expansion. But pulp prices alone do not determine expansion anymore. Pulpwood plantations can be transformed into charcoal or other energywood projects, as happened with Celmar, a failed 1990s pulp project in Brazil's M aranhão (Kröger 2013b). Therefore, boom-bust market cycles as drastic as in cacao or other edible crops will not likely be seen (although, being a vulnerable monoculture, destruction of plantations might be experienced due to epidemic diseases or uncontrollable fires; these being a growing possibility as the size of monocultures and climate disruptions increase).

TPs are marketed as a way to replace fossil fuels and new pulp mills are becoming major energy producers (Fontes 2012). Wood-based second generation biodiesel-plants are also being erected, with high hopes in the industry that wood-fuel could become the next oil. UPM is setting up now the world's first wood-based biodiesel plant in Finland in Lappeenranta, and is confident that wood biodiesel will become for it alone a multi-billion-euro business in a few years (UPM 2014; also based on interviews of directors in Finnish news broadcasts in 2012). Also, the Finnish Stora Enso and Neste Oil are able already to obtain ethanol by gasifying wood residues, and can build similar biorefineries to UPM (WRM 2008). 
Genetic manipulation and other new technologies are also helping to expand future TPs. A myriad of genetically-modified (GM) and nanotechnology paper applications are being developed based on the capitalization of specially engineered trees (Uronen 2010). $\stackrel{18}{=}$ An especially fast-growing area is the engineering of trees to maximize production of wood biomass-based ethanol (WRM 2008, Kuusi 2010). The machinery and technology development is still largely controlled by Northern companies, but fast-growth and flex plantation techniques, including GM trees, are an area of innovation where Southern companies such as Suzano from Brazil are gaining a strong foothold (Vidal 2012)..$^{\frac{19}{9}}$ It is likely these strands will unite even more tightly into a global flex-forestry cluster. This industry consolidation will lead to further expansion. Tree plantations are becoming flex tree plantations. This is a step further in the process of nature commoditization, which signifies the creation of deeper capitalism.

The ecologies and inputs for production of these flex tree plantations differ from traditional TPs. For example, Suzano's eucalyptus pellet investment in Brazil's M aranhão state's northeastern part relies on two-year rotation eucalyptus plantations (field research, M arch 2011; this project has been discontinued by local resistance, Kröger $\underline{2013 \mathrm{~b}}$ ). Faster-growth TPs are bound to be more damaging to the soil according to the Soil and Plantation manager of Veracel (interview, 20 July 2006, Eunápolis), due to their faster rotation. Inputs also vary, typically making these larger, as most pesticides (principally glyphosate) and fertilizers are introduced in the planting phase, these increasing as rotation comes faster. As the energy-uses of timber are starting to be ever more viable and called for, the pressure on forests will be such that the conversion of timber into an ever more clearly flex crop used not just for the forest industry but even more for the energy industry (already now half of trees cut are used as fuel, argue Dauvergne and Lister 2011) will result in a far greater push to establish flex TPs.

\section{Concluding remarks}

This contribution has analysed tree plantation expansion based on a review of the existing knowledge. Wright's (2005) and Polanyi's (2001) conceptualizations of capitalism, commoditization and class were used to study the political causalities and agency in the expansion of tree plantations and the divisions and relations between these were studied by using a Bourdiean $(1990,1991,1998)$ analysis of social, symbolic and territorial spaces. The method of incorporated comparison (M cM ichael 1992) was used to study why and how tree plantations have been expanded throughout history in different world historical conjunctures, across space and time.

A pruning of the FAO, CIFOR and other data available demonstrates that perhaps the grandest challenge and most urgent research task is to more tightly define what are tree plantations and what are forests, and produce more solid databases, more carefully. The available data demonstrated 'planted forests' have expanded dramatically between 1990 and 2010 (to 264 million ha, a 48 percent increase), expanding at a rate of over 5 million ha per year globally. This figure is rising, and leading to massive transformation of diverse landscapes into uniform single species TPs. Governments have amply supported the process, while resistance has managed to bar expansion in a considerable number of political systems.

Global and local divisions of profits and power that have resulted from TP expansion were considered. China has risen to a mixed but prominent global position, being the world's largest paper producer, whilst having also its own ITP expansion. Other countries of the South have remained commodity producers, exporting pulp, while the North has retained its position. Ever more merged key companies, elites and pension fund managers 
have increased their power and rights in the deployment of labour and means of production in would-be TP spaces. Following the conceptualization of class by W right (2005), this signifies that class cleavages have increased. Symbolic and territorial changes, via TP expansion and discourses legitimizing this, have boosted the changes in social space, in class relations, resulting in greater capital accumulation, power and land control to few hands. The commoditization of land has been central in this creation of capitalism, as Polanyi (2001) already theorized. This has happened particularly in the ITP expansion areas. Those benefiting from the rise of Southern pulp giants have been the local elites, not the landless labourers or displaced peasants and indigenous populations.

Both global unity and variety in expansion style were found. TP expansion in general has been driven by corporations, although in some contexts smallholder TPs (e.g. Vietnam, Thailand) and public TPs (China) have been much more important. Even in STP expansion areas, the landless and others not becoming capitalist farmers have been dispossessed. The power and rights of those rural people who have managed to establish STPs over the cultivated areas has increased, often at the cost of other people's right to use land.

Concomitantly, socio-environmental damage has been occurring across all types of TPs. In the symbolic space, legitimizing discourses that define forests or lands as 'degraded' and 'unused' have been used to justify TP expansion, while these claims have not been based on actual facts. Enclosures of territory have led to establishment of ITPs as rent bases for elites, retained by use of physical and structural violence. The displaced surplus populations have faced rural exodus, only a small portion being incorporated as landless labourers. This incorporation has at times been forced, offering in the best case only poorly remunerated jobs. Stronger control, capital accumulation and creation of property rights into nature are also reasons behind the current drive to introduce GM trees.

Some have seen potential in smallholder tree plantations. Considering their developmental and socioenvironmental impacts, many argue a better solution would be for smallholders to plant individual trees or focus on natural regeneration forests rather than on STPS. STPs can produce gains for smallholders if alternative timber markets exist (e.g. Thailand). Yet those deprived of access suffer also from the implementation of small-scale forestry capitalism.

The same TPs can be used in ever more numerous ways, including as pulpwood, energywood or 'carbon sinks'. The rapidly changing global economy and nature require flexibility and rapid adaptability: thus, flex tree plantations have inbuilt survival skills as they increase the range of possible timber uses. M ost importantly, the (overtly exaggerated) potential cast on them as a renewable capitalist answer to the depletion of nonrenewable resources carries great symbolic capital, usable in marketing discourses to attract investors. Flex TPs continue to expand, forming entire landscapes of phony forests of single species, if resistance does not challenge the expansion. When the impacted populations have struggled against the expansion projects by acts in the symbolic, territorial and social space (by discursive and other re-symbolizations, land occupations and other protests, and mobilization into social movements), they have managed to slow down and discontinue expansion (Kröger 2011, 2013a).

This review suggests that even though there is a need for many more critical studies to accompany the ever more rapid expansion, there is already a growing, and empirically and theoretically rigorous, literature. TP 
expansion, environmental impacts and developmental consequences have been studied much more than TP conflict dynamics.

As non-food land use changes, TP establishment should be integrated more fully into the debate on land grabbing. The findings here should be compared to other types of recent land grabbing. Comparison of the forest industry plantations to agricultural plantations such as oil palm and rubber could illustrate the interindustry similarities and differences in the expansion logics and impacts.

I would like to thank J un Borras and three anonymous reviewers for their excellent remarks, and Winnie Overbeek, Jan-Erik Nylund and Larry Lohmann for very constructive comments on some parts of the paper. The research was funded by the Academy of Finland.

\section{Notes}

'Bio' and 'green' are placed in quotation marks here, as many argue that fast-growing TPs and other new investments labelled as green and bio are not really sustainable. For example, the use of petrochemicals in many biofuel plantations renders them as not green and bio enough to deserve the label that has a connotation of sustainability (see Böttcher and Lindner 2010).

${ }^{2}$ Food and oil markets and companies define palm oil prices and production, not timber markets or forest companies. Forest, oil and food industries have different logics, and the planting of oil palm differs significantly in terms of labour and capital relations from the forest industry. See M cCarthy (2010) for a study on the commodity-specific characters of oil palm, including the ways in which oil palm plantations 'have agency' and influence human practices. From the viewpoint of peasant studies, one key difference is that oil palm requires much more labour-force than TPs, which can be much more mechanized.

${ }^{3}$ In contrast to tree plantations in general, rubber plantations have not expanded much, their area being about 8 million hectares in 1990 and 10 million hectares in 2010 according to FAO (2010). The study of rubber is useful in illustrating the emergence of the flex tree complex: from metal and chemical industry use, old rubber plantations turn to (wood) energy use. However, the relative insignificance of rubber plantations in the global picture, and non-usability as timber in the forest industry, suggested an only cursory exploration of them in this review.

${ }^{4}$ There are over 600 known eucalyptus species, of which about 20 are currently widely used commercially. Hybrids such as E. globulus and E. urograndis are common, the first providing the best quality fiber for pulp and papermaking and used for example in Portugal, and the latter being the fastest growing, used particularly in Brazil. Breeders constantly develop new clones of eucalyptus and pine species. All the pine and eucalyptus species will be referred to as simply pine and eucalyptus.

${ }^{5}$ There is a wide variety of corporations and smallholders. Smallholders are defined here (based on induction from empirical evidence in TP cases) as those family farmers who have direct and preferential access to land and are partially self-sufficient, partially engaged with markets. Smallholders here differ from peasants (as distinguished by Watts 2009a, 524) in that they are not necessarily self-sufficient at all (all of their land may be planted with trees sold for money that buys food), may not be subordinate actors in larger political economies such as national timber markets, and may be autonomous and not fulfilling obligations to holders of political 
and economic power. A smallholder has control over the rights and power in the deployment of labour and means of production in a space which spans a few hectares territorially.

${ }^{6}$ Pokorny et al. (2010) consider that traditional communities' TPs are also a form of smallholder plantation, alongside individual farmers' TPs. In this contribution, STPs signify home and family farming and other smallscale (up to 20 ha, varying across contexts) individually-controlled TPs. In contrast to the four types of TPs presented in this paper, CIFOR's (Center for International Forestry Research) five-fold typology (CIFOR 2001, Kanninen 2010, 3) looks at the industrial-non-industrial use separation (quite common in forestry science), the production purpose and style, rather than power relations. The typology here, on the other hand, distinguishes social actors that control TPs (corporate, smallholder, public and community).

${ }^{7}$ For a theoretical study on when, where and why resistance and TP conflict surges, see Kröger (2013b); for a global review of TP conflicts, see Gerber (2010).

${ }^{8}$ When differences of capital are misperceived as differences of honor, they function as what Bourdieu calls symbolic capital (Bourdieu 1991, 238).

${ }^{9}$ The World Rainforest M ovement (WRM , the most well-known and consistent NGO criticizing ITPs, with a large production of publications, research and data on the topic) and various other NGOs as well as hundreds of scientists and citizens have been campaigning for more than a decade to try to change the FAO definition of forests, arguing the agency is captured by the wood-based industry (see WRM 2011a, 2011b).

${ }^{10}$ The concept of 'planted forest' was introduced in the early 2000s. It is a much broader concept than the older 'forest plantation', roughly doubling the size of plantations in FAO statistics (Kanninen 2010). FAO (2004) conceptualizes 'forest plantations' as having 'few species, even spacing and/or even-aged stands'. In contrast, 'planted forests' can have many species of different age in stands, and uneven spacing, and are defined as 'predominantly composed of trees established through planting and/or after deliberate seeding of native or introduced species' (Carle and Holmgren 2008). The latter category of 'planted forests' includes thus natural forest-looking tree stands, semi-natural forests that non-foresters typically do not consider 'plantations'. In studying TPs per se, 'forest plantation' data would be more precise. However, the FAO data does not offer data on 'forest plantations' anymore.

${ }^{11}$ However, FAO (2010) presents M exico as having had no tree plantations at all in 1990; in FAO (2011) the figure for $1990 \mathrm{M} \mathrm{exico}$ is 350,000 ha. When I asked about the discrepancy, an FAO official responded by email that 350,000 ha seems like a mistake, but could not give definite answer on why there is a mistake, or if this is a mistake. If the figure is zero, then the TP growth in M exico has been even higher than 815 percent.

${ }^{12}$ FAO 2011 counts North Africa twice: it considers this region to belong to both Africa and Near East. For this reason the global total of FAO data does not match with the sub-parts. I have corrected this error in Table 1 by removing North Africa from Near East data, making the global sum match with regional figures.

${ }^{13}$ Whereas the corporate TP expansion is relying almost solely on exotic tree-species monocultures (Del Lungo et al. 2006, FAO 2010) - the 6.14 million ha ITP increase figure (1990-2005) being thus an expression of true ITP expansion - a large part of the smallholder, community and public 'planted forests' are not exotic-species monocultures managed intensively. 
${ }^{14}$ The more embedded a contentious actor is in political games in relation to industry embedding, the more likely it will achieve its goals - other strategies supporting it (Kröger 2013a).

${ }^{15}$ For example, India, with 70 percent public ownership, had only 13 percent of exotic plantations (FAO 2010), but in Chile, with 70 percent corporate ownership (Del Lungo et al. 2006), 100 percent of plantations were exotic (FAO 2010). See Nylund and Kröger (2012) for further analysis on the cleavage in the understanding of sustainability between the industry and the local communities.

${ }^{16}$ M ost of this prognosis is overtly unrealistic, used as marketing discourses by companies seeking to attract speculative investors to finance them; see e.g. the discourses by genetically modified (GM)-eucalyptus developers in Vidal (2012).

${ }^{17}$ The prices for NBSK, Northern bleached softwood kraft pulp (the industry's benchmark grade of pulp), in the U.S. were over USD 1,000 per ton in February 2014 (FOEX Indexes Ltd 2014). This is a very high figure; consequently, streamlined mills have margins of about 40 percent (Kröger 2012a). Insofar as commodity prices rise, as they have done, those who got in early in land markets will be happy with their established corporate enclaves.

${ }^{18}$ Examples include nanocellulose fibres to create material with different penetration, reflection and other speciality qualities, which can be of use in many industries. Cellulose nanofibres are potentially much stronger than synthetic fibres, and have much smaller diameters, allowing for specialty use. This way, much stronger papers could be produced, and also medical industry and electronic applications could use these products, argue the proponents of the technology (Coughlin n.d.)

${ }^{19}$ Although most GM tests on non-flowering trees in the world are done in Finland, Brazil is about to legalize GM eucalyptus, having already given permits for trials, for example, and all around the world there are test sites (Kuusi 2010). China is the only place that has given permission to plant GM trees on any scale, having 1 million GM pines (Vidal 2012).

\section{References}

1. Bacchetta, V. 2012. La soberianía a la deriva. Ecoportal.net, 13 September.

2. Baird, I. 2011. Turning land into capital, turning people into labor: primitive accumulation and the arrival of large-scale economic land concessions in the Lao People's Democratic Republic. New Proposals: Journal of Marxism and Interdisciplinary Inquiry, 5(1), 10-26.

3. Barney, K. 2004. Re-encountering resistance: plantation activism and smallholder production in Thailand and Sarawak, M alaysia. Asia Pacific Viewpoint, 45(3), 325-39. doi: 10.1111/j.1467-8373.2004.t01-1-00244.x [CrossRef]

4. Barr, C. and J. Sayer. 2012. The political economy of reforestation and forest restoration in Asia-Pacific: critical issues for REDD+. Biological Conservation, 154, 9-19. doi: 10.1016/j.biocon.2012.03.020 [CrossRef], [Web of Science $₫]$ 
5. Borras, S.M., 2012. Land grabbing in Latin America and the Caribbean. Journal of Peasant Studies, 39(3-4), 845-72. doi: 10.1080/03066150.2012.679931 [Taylor \& Francis Online], [Web of Science $₫$ ]

6. Böttcher, H. and M. Lindner. 2010. M anaging forest plantations for carbon sequestration today and in the future. In: J. Bauhus, eds. Ecosystem goods and services from plantation forests. London: Earthscan, pp. 43- 76.

7. Boulay, A. and L. Tacconi. 2012. The drivers of contract eucalypt farming in Thailand. International Forestry Review, 14(1), 1-12. doi: 10.1505/146554812799973190 [CrossRef]

8. Bourdieu, P. 1990. In other words: essays towards a reflexive sociology. Stanford: Stanford University Press.

9. Bourdieu, P. 1991. Language and symbolic power. Cambridge: Polity Press.

10. Bourdieu, P. 1998. Practical reason: on the theory of action. Cambridge: Polity Press.

11. Bull, G. 2006. Industrial forest plantation subsidies: impacts and implications. Forest Policy and Economics, 9, 13-31. doi: 10.1016/j.forpol.2005.01.004 [CrossRef], [Web of Science ®]

12. Bunker, S. and P. Ciccantell. 2005. Globalization and the race for resources. Baltimore: The John Hopkins University Press.

13. Carámbula, M., V. M enéndez and D. Piñero. 2011. La expansión de capital forestal en el agro Uruguay. Conference proceeding, VII Jornadas Interdisciplinarias en Estudios Agrarios y Agroindustriales, University of Buenos Aires.

14. Carle, J. and P. Holmgren. 2008. Wood from planted forests: a global outlook 2005-2030. Forest Products

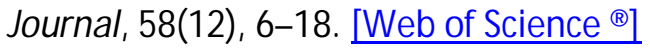

15. Carrere, R. and L. Lohmann. 1996. Pulping the South: industrial tree plantations and the world paper economy. London: Zed Books.

16. CIFOR. 2001. Typology of Planted Forests. CIFOR InfoBrief, Center for International Forestry Research.

17. Clapp, R.A. 1998. Regions of refuge and the agrarian question: peasant agriculture and plantation forestry in Chilean Araucania. World Development, 26(4), 571-89. doi: 10.1016/S0305-750X(98)00010-2 [CrossRef],

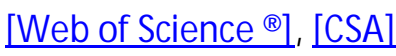

18. Coughlin, D. (no date) Nanotechnology and the paper/forest product industry, SAPPI. Available from: http://www.nanotechforest.org/Scopi/Group/nano/scp01nan.nsf [Accessed 30 November 2012].

19. Dauvergne, P. and J. Lister. 2011. Timber. Cambridge: Polity.

20. Del Lungo, A., J. Ball and J. Carle. 2006. Global planted forests thematic study: results and analysis. Planted Forests and Trees Working paper 38. Rome: FAO. 
21. Fairhead, J., M. Leach and I. Scoones. 2012. Green grabbing: a new appropriation of nature? Journal of Peasant Studies, 39(2), 237-61. doi: 10.1080/03066150.2012.671770 [Taylor \& Francis Online], [Web of Science $\mathbb{B}$

22. FAO. 2004. Global forest resources assessment update 2005. Terms and definitions. Forest Resources Assessment WP 83.

23. FAO. 2010. Global forest resources assessment 2010.

24. FAO. 2011. State of the world's forests 2011.

25. FAO. 2012. State of the world's forests 2012.

26. FAO (no date). Definitions Related to Planted Forests. Available from: http://www.fao.org/docrep/007/ae347e/AE347E02.htm

27. Fearnside, P. 1998. Plantation forestry in Brazil: projections to 2050. Biomass and Bioenergy, 15(6), 437450. doi: 10.1016/S0961-9534(98)00061-0 [CrossRef], [Web of Science ®]

28. Ferreira, S. 2009. "Donos do lugar": a territorialidade quilombola do Sâpe do Norte - ES. PhD dissertation, UFF, Niterói.

29. Finnish Forest Association. 2012. Finnish forests - owned by Finns. Website, updated on 3 January 2012: Available from: http://www.forest.fi/smyforest/foresteng.nsf/allbyid/2060D041E6A0B051C2256F25003E4B8D?Opendocumen t [Accessed 16 February 2014].

30. Flaten, K. 2011. Tree plantation expansion: Impacts on rural communities in the Central North of Tasmania. ISP Collection, Paper 1078.

31. FOEX Indexes Ltd. 2014. Latest PIXIndex Values With Comments. Available from: http:// foex.fi/ [Accessed 16 February 2014].

32. Fontes, S. 2012. Produtor de celulose cresce em geração. Valor Econômico, 11 September.

33. Fox, J. 2009. Policies, political-economy, and swidden in Southeast Asia. Human Ecology, 37(3), 305-22. doi: 10.1007/s10745-009-9240-7 [CrossRef], [Web of Science ®]

34. Gerber, J.-F. 2010. Conflicts over industrial tree plantations in the South: who, how and why?. Global

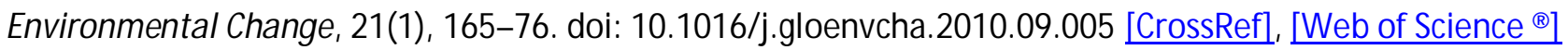

35. Gerber, J.-F. and S. Veuthey. 2010. Plantations, resistance and the greening of the agrarian question in coastal Ecuador. Journal of Agrarian Change, 10, 455-81. doi: 10.1111/j.1471-0366.2010.00265.x [CrossRef], [Web of Science $\mathbb{~}$ ]

36. Gidvani, V. 2009. Class. In: D. Gregory et al., eds. The Dictionary of Human Geography. Chichester: WileyBlackwell, pp. 88-9. 
37. Global Wood Trade Network. 2011. China wood products prices 1-15th February 2011.

38. Gonçalves, M.T. 2001. Nós da madeira: mudança social e trabalhadores assalariados das plantações florestais nos Vales do Aço/Rio Doce de M inas Gerais. Thesis (PhD), UFFRJ.

39. Gopalakrishnan, S. 2012. Undemocratic and arbitrary: control, regulation and expropriation of India's forest and common lands. New Delhi: SPWD. Washington, DC: RRI.

40. Hall, D. 2002. Environmental change, protest, and havens of environmental degradation: evidence from Asia. Global Environmental Politics, 2(2), 20-28. doi: 10.1162/15263800260047808 [CrossRef], [CSA]

41. Hanssen, C.H. 2007. Lao land concessions, development for the people? Conference on Poverty Reduction and Forests, Bangkok. Available from: http://www.mtnforum.org/sites/default/ files/pub/4948.pdf

42. Harari, I. 2013. M onocultura do eucalipto ataca trabalhadores rurais. Caros Amigos, 4 January.

43. Jackson, R. 2005. Trading water for carbon with biological carbon sequestration. Science, 310, 1944-7. doi: 10.1126/science. 1119282 [CrossRef], [PubM ed], [Web of Science $₫$ ]

44. Jobbágy, E., G. Baldi and M. Nosetto. 2012. Tree plantation in South America and the water cycle: impacts and emergent opportunities. In: T. Schlichter and L. Montes, eds. Forests in development: a vital balance. Springer, pp. 53-63.

45. Kanninen, M. 2010. Plantation forests: global perspectives. In: J. Bauhus, eds. Ecosystem goods and services from plantation forests. London: Earthscan, pp. 1-15.

46. Karumbidza, J.B. 2005. A study of the social and economic impacts of industrial tree plantations in the KwaZulu-Natal Province of South Africa. WRM : M ontevideo.

47. Kassa, H., M. Bekele and B. Campbell. 2011. Reading the landscape past: explaining the lack of on-farm tree planting in Ethiopia. Environment and History, 17(3), 461-79. doi: 10.3197/096734011X13077054787262

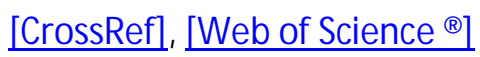

48. Kröger, M. 2011. Promotion of contentious agency as a rewarding movement strategy: evidence from the M ST-paper industry conflicts in Brazil. Journal of Peasant Studies, 38(2), 435-58. doi:

10.1080/03066150.2011.559016 [Taylor \& Francis Online], [W eb of Science $₫]$

49. Kröger, M . 2012a. The expansion of industrial tree plantations and dispossession in Brazil. Development and Change, 43(4), 947-73. doi: 10.1111/j.1467-7660.2012.01787.x [CrossRef], [Web of Science ®]

50. Kröger, M . 2012b. Neo-mercantilist capitalism and post-2008 cleavages in economic decision-making power in Brazil. Third World Quarterly, 33(5), 887-901. doi: 10.1080/01436597.2012.674703 [Taylor \& Francis Online], [Web of Science $\mathbb{B}$ ]

51. Kröger, M. 2013a. Contentious agency and natural resource politics. London: Routledge. 
52. Kröger, M. 2013b. Grievances, agency and the absence of conflict: The new Suzano pulp investment in the Eastern Amazon. Forest Policy and Economics, 33, 28-35.

53. Kröger, M . 2013c. Globalization as the "pulping" of landscapes: forestry capitalism's North-South territorial accumulation. Globalizations, 10(6), 837-853. doi: 10.1080/14747731.2013.814433 [Taylor \& Francis Online], [Web of Science $\mathbb{B}$ ]

54. Kröger, M . and J. Nylund. 2012. The conflict over Veracel pulpwood plantations in Brazil: application of Ethical Analysis. Forest Policy and Economics, 14, 74-82. doi: 10.1016/j.forpol.2011.07.018 [CrossRef], [Web of Science $\mathbb{B}$

55. Kumar, N., N. Saxena, Y. Alagh and K. M itra. 2000. India, Alleviating Poverty through Forest Development. Washington, DC: World Bank Operations Evaluation Department.

56. Kuusi, 0. 2010. Geenimuuntelun nykyinen ja tuleva käyttö puiden kehittämisessä. In: O. Kuusi , eds. Löytöretkiä biopolitiikkaan. Helsinki: Finnish Parliament, Committee for the Futures, pp. 119-120.

57. Leys, A.J. and J.K. Vanclay. 2010. Land-use change conflict arising from plantation forestry expansion: views across Australian fence-lines. International Forestry Review, 12(3), 256-269. doi: 10.1505/ifor.12.3.256 [CrossRef]

58. Li, T.M . 2011. Centering labor in the land grab debate. Journal of Peasant Studies, 38(2), 281-98. doi: 10.1080/03066150.2011.559009 [Taylor \& Francis Online], [Web of Science $₫$ ]

59. Little, C., 2009. Revealing the impact of forest exotic plantations on water yield in large scale watersheds in South-Central Chile. Journal of Hydrology, 374, 162-70. doi: 10.1016/j.jhydrol.2009.06.011 [CrossRef], [Web of Science $₫$

60. Lohmann, L. 1999. The carbon shop: planting new problems. M ontevideo: WRM.

61. Marchak, P. 1995. Logging the globe. Montreal: McGill-Queen's University Press.

62. M cCarthy, J. 2010. Processes of inclusion and adverse incorporation: oil palm and agrarian change in Sumatra, Indonesia. The Journal of Peasant Studies, 37(4), 821-850. doi: 10.1080/03066150.2010.512460 [Taylor \& Francis Online], [PubM ed], [Web of Science $\left.{ }^{\circledR}\right]$

63. M cElwee, P. 2009. Reforesting "bare hills" in Vietnam: social and environmental consequences of the 5 million hectare reforestation program. AM BIO: A Journal of the Human Environment, 38(6), 325-333. doi: 10.1579/08-R-520.1 [CrossRef]

64. M cM ichael, P. 1992. Rethinking comparative analysis in a post-developmental context. International social science journal, 133, 351-65.

65. Mercer, D. and A. Underwood. 2002. Australian timber plantations: national vision, local response. Land Use Policy, 19, 107-122. doi: 10.1016/S0264-8377(02)00005-4 [CrossRef], [Web of Science ®] 
66. du M onceau, M.I. 2008. The political ecology of indigenous movements and tree plantations in Chile. Thesis (PhD), University of British Columbia.

67. Nagashima, K., 2002. Regional landscape change as a consequence of plantation forestry expansion: an example in the Nelson region, New Zealand. Forest Ecology and M anagement, 163(1-3), 245-261. doi: 10.1016/S0378-1127(01)00583-7 [CrossRef], [Web of Science ®], [CSA]

68. Nahuelhual, L., 2012. Land-cover change to forest plantations: proximate causes and implications for the landscape in south-central Chile. Landscape and Urban Planning, 107(1), 12-20. doi:

10.1016/j.landurbplan.2012.04.006 [CrossRef], [Web of Science ®]

69. Nylund, J. and M. Kröger. 2012. Cleavage in the understanding of sustainability: sustainable pulp industry versus sustained local livelihood. Scandinavian Journal of Forest Research, 27(2), 229-40. doi:

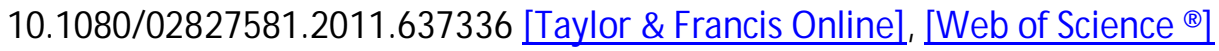

70. Obidzinski, K. and A. Dermawan. 2010. Smallholder timber plantation development in Indonesia: what is preventing progress? International Forestry Review , 12(4), 339-348. doi: 10.1505/ifor.12.4.339 [CrossRef], [Web of Science $\mathbb{~}]$

71. Overbeek, W., M. Kröger and J. Gerber. 2012. An overview of industrial tree plantations in the global South: Conflicts, trends and resistance struggles. Ejolt Report Number 3.

72. Patterson, M.W. and N. Hoalst-Pullen. 2011. Dynamic equifinality: the case of south-central Chile's evolving forest landscape. Applied Geography, 31(2), 641-49. doi: 10.1016/j.apgeog.2010.12.004 [CrossRef], [Web of Science $\mathbb{B}$

73. Peluso, N.L. and P. Vandergeest. 2001. Genealogies of forest law and customary rights in Indonesia, M alaysia, and Thailand. J. Asian Stud., 60(3), 761-812. doi: 10.2307/2700109 [CrossRef], [Web of Science ®]

74. Ping, L. and R. Nielsen. 2010. A case study on large-scale forestland acquisition in China. The Rights and Resources Initiative. Available from: http://www.rightsandresources.org/documents/files/doc_1800.pdf

75. Pirard, R. and J. M ayer. 2009. Complementary labor opportunities in Indonesian pulpwood plantations with implications for land use. Agroforestry Systems, 76(2), 499-511. doi: 10.1007/s10457-008-9141-6 [CrossRef],

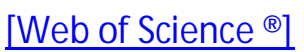

76. Pokorny, B., L. Hoch and J. M aturana. 2010. Smallholder plantations in the tropics - local people between outgrower schemes and reforestation programmes. In: Bauhus, eds. Ecosystem goods and services from plantation forests. London: Earthscan, pp. 140-70.

77. Polanyi, K. 2001. The great transformation: the political and economic origins of our time. Boston: Beacon Press.

78. Puntasen, A., S. Siriprachai and C. Punyasavatsut. 1992. Political economy of eucalyptus: business, bureaucracy and the Thai government. Journal of Contemporary Asia, 22(2), 187-206. doi:

$10.1080 / 00472339280000151$ [Taylor \& Francis Online], [Web of Science ®], [CSA] 
79. RISI. 2011. The PPI Top 100. Available from: http:// www.risiinfo.com/techchannels/papermaking/The-PPITop-100-2010-stayed-the-course.html [Accessed 6 January 2013].

80. Ross, M.L. 2001. Timber booms and institutional breakdown in South East Asia. Cambridge: Cambridge University Press. [CrossRef]

81. Rudel, T.K. et al. 2005. Forest transitions: towards a global understanding of land use change. Global Environmental Change, 15(1), 23-31.

82. Sargent, C. and S. Bass, eds. 1992. Plantations politics: forest plantations in development. London: Earthscan.

83. Sarin, M. 2003. Devolution as a threat to democratic decision-making in forestry? Findings from three states in India. London: Overseas Development Institute.

84. Saxena, N.C. 1997. The Saga of Participatory Forest M anagement in India. Bogor: CIFOR.

85. Scott, J. 1998. Seeing like a state: how certain schemes to improve the human condition have failed. London: Yale University Press.

86. Scott, J. 2009. The art of not being governed. London: Yale University Press.

87. Sekher, M. 2001. Organized participatory resource management: Insights from community forestry practices in India. Forest Policy and Economics, 3, 137-54.

88. Shiva, V. and J. Bandyopadhyay. 1985. Ecological audit of eucalyptus cultivation. Dehradun: The English Book Depot.

89. Sikor, T. 2012. Tree plantations, politics of possession and the absence of land grabs in Vietnam. Journal of Peasant Studies, 39(3-4), 1077-101. doi: 10.1080/03066150.2012.674943 [Taylor \& Francis Online], [Web of Science $₫$

90. Sikor, T. and T.Q. Nguyen. 2007. Why may forest devolution not benefit the rural poor? Forest entitlements in Vietnam's Central Highlands. World Dev., 35, 2010-2025. doi: 10.1016/j.worlddev.2006.11.011 [CrossRef], [Web of Science $₫]$

91. Spek, M. 2006. Financing pulp mills: an appraisal of risk assessment and safeguard procedures. Bogor: CIFOR.

92. Stewart, H.T.L., D.H. Race and A.L. Curtis. 2011. New forests in changing landscapes in South-East Australia. International Forestry Review , 13(1), 67- 79. doi: 10.1505/146554811798201206 [CrossRef]

93. Swedish Forest Industries Association. 2010. The Swedish forest industries: Facts and figures 2009. Stockholm.

94. UNEP. 2012. Global environment outlook (GEO-5). 
95. UPM . 2014. About UPM / Biofore in Action / From residue to renewable diesel. Available from: http://www.upm.com/EN/ABOUT-UPM/biofore-in-action/from-residue-to-renewablediesel/Pages/default.aspx [Accessed 16 February 2014].

96. Uronen, T. 2010. On the transformation processes of the global pulp and paper industry and their implications for corporate strategies - A European perspective. Thesis (PhD), Aalto University.

97. Vandergeest, P. and N.L. Peluso. 2006. Empires of forestry: professional forestry and state power in Southeast Asia, part 2. Environment and History, 12, 4359-393.

98. Vidal, J. 2012. The GM tree plantations bred to satisfy the world's energy needs. The Guardian, 15 November.

99. Watts, M. 2009a. Peasant. In: Gregory, eds. The dictionary of human geography. Chichester: WileyBlackwell, pp. 524-5.

100. van Wilgen, B. and D.M. Richardson. 2012. Three centuries of managing introduced conifers in South Africa: benefits, impacts, changing perceptions and conflict resolution. Journal of Environmental M anagement,

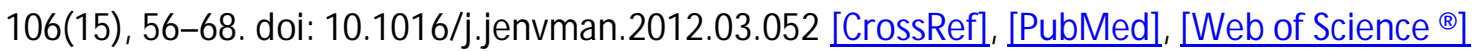

101. Wright, E.O. 2005. Foundations of a neo-M arxist class analysis. In: E.O. Wright, ed. Approaches to class analysis. Cambridge: Cambridge University Press, pp. 4-30. [CrossRef]

102. WRM. 2007. Working conditions and health impacts of industrial tree monocultures. M ontevideo.

103. WRM. 2008. Ethanol from Cellulose: a technology that could spell disaster. M ontevideo.

104. WRM. 2011a. The definition of forest: WRM Briefing. M ontevideo.

105. WRM . 2011b. Definition of Forest Campaign. Open letter from scientists to the FAO. Available from: http://www.wrm.org.uy/oldsite/forests/letter_to the_FAO.html [Accessed 16 February 2014].

106. Yang, L. 2011. Internal Social Work Assessment Report on StoraEnso Guangxi Forest Operation Areas. Not published. 